\title{
Spokes in the Wheels of CLIL for Multilingualism or How Monolingual Ideologies Limit Teacher Training
}

\author{
Otilia Martí ${ }^{1} \&$ Laura Portolés ${ }^{1}$ \\ ${ }^{1}$ Faculty of Humanities and Social Sciences, Universitat Jaume I, Castelló, Spain \\ Correspondence: Otilia Martí, Faculty of Humanities and Social Sciences, Universitat Jaume I, Castelló, Spain.
}

Received: September 26, 2018 Accepted: January 5, 2019 Online Published: January 8, 2019

doi: 10.5539/elt.v12n2p17 URL: https://doi.org/10.5539/elt.v12n2p17

\begin{abstract}
In line with van Kampen et al.'s (2018) research about specialist and practitioner perceptions on the goals for CLIL in the Netherlands, the present study addresses Hüttner, Dalton-Puffer and Smit's (2013) call for investigating teachers' beliefs about CLIL in European countries like Spain where this teaching approach is highly institutionalized. Unlike the aforementioned studies, though, ours focuses on novice subject teachers in Primary education. More specifically, it links teacher cognition and pre-service or initial teacher training with the aim of exploring the extent to which student teachers' beliefs mediate their education. The analysis of how these student teachers understand the aims and language principles of CLIL unveils the role that a set of monolingual ideologies (e.g. "the English only policy") play in the conceptualization and consequent acceptance or disapproval of this teaching approach. As we also pay heed to the impact of tertiary instruction on participants' beliefs, implications for CLIL teacher preparation programmes are discussed.
\end{abstract}

Keywords: multilingualism, CLIL, teachers' beliefs, teacher training, monolingual ideologies

\section{Introduction}

Since its inception in the mid-1990s, CLIL programmes have been said to be "mushrooming in many different contexts" (Merino \& Lasagabaster, 2015, p. 79), or to be "growing exponentially" (Juan-Garau \& Salazar-Noguera, 2015 , p. 3). Hence, the image of wheels that entitles this paper is put forward to remark the dynamic nature of a fast developing phenomenon that seems to be unstoppable worldwide. Defined as "a dual-focused educational approach in which an additional language is used for the learning and teaching of both content and language" (Coyle et al., 2010, p. 1), this term has proven to be controversial on a number of fronts, starting with its very same characterization. The "terminological and pedagogical vagueness of CLIL" (Pérez Cañado, 2016a, p. 18) affects not only how CLIL is understood but also the way this teaching approach is implemented.

The strong link existing between conceptualization and acceptance or disapproval of CLIL derives from the fact that, with the exception of CLIL provisions in the Netherlands or Spain, the swift spreading of this teaching approach has been mostly the result of bottom-up initiatives (Dalton-Puffer et al., 2010, p. 4; Ruiz de Zarobe, 2013 , p. 232). Taking into account that CLIL can be seen as language policy "from below" or "as a kind of self-organising system" (Hüttner et al., 2013, p. 280), examining the views of stakeholders (teachers, parents and learners) has found a place in the CLIL research agenda. As far as teachers are concerned, their willingness or reluctance to put CLIL into practice greatly depends on the extent to which its aims are clearly understood (Pavón \& Méndez, 2017) or perceived as attainable and/or beneficial. A number of studies carried out in Europe have allowed us to gain some insights into teachers' beliefs about CLIL. Yet, most of this extant literature has been conducted with experienced practitioners and/or in contexts where CLIL provision has not been instituted from above (Hüttner et al., 2013).

\section{Theoretical Framework}

\subsection{Multilingualism and CLIL}

From a high-level policymaking perspective, CLIL has been advocated by the European Union as a teaching approach to promote multilingualism at all educational levels (see European Commission, 1995, p. 47). Welcome as a strategy to enforce the $1+2$ formula for achieving proficiency in three European languages, with two additional languages besides the first one, the political support in favour of implementing this approach has 
contributed to aligning CLIL with an improved version of second or foreign language learning and teaching (Cenoz et al., 2014; Dalton-Puffer, 2011; Serra, 2007). This greater emphasis on the language learning dimension of CLIL over its content learning side has been accentuated by two additional reasons: most researchers in the field are language educators (Ruiz de Zarobe \& Cenoz, 2015), and many of the core tenets of CLIL are drawn from second language acquisition (henceforth, SLA) theories, like the widely questioned but still influential Krashen's Input Hypothesis (Dalton-Puffer, 2011; de Graaff et al., 2007; Pérez-Vidal, 2015; or, Ruiz de Zarobe \& Cenoz, 2015; for an analysis of CLIL from a SLA psycholinguistic perspective, see Muñoz, 2007).

According to Dalton-Puffer and Smit (2007), some of the most extended pro-CLIL arguments are based on these SLA theoretical underpinnings. When this teaching approach is said to promote naturalistic language learning in opposition to formal language instruction, to provide more quantity and better quality input, or to develop interaction and focus on meaning instead of forms, CLIL is presented as the embodiment of Communicative Language Teaching "on a grand scale" (Dalton-Puffer \& Smit, 2007, p. 8). The potential danger here is reducing the aims of CLIL to language learning gains by merely increasing the exposure to a second language (Lo, 2015). This does not only hinder one of the main goals of CLIL, namely, the dual focus on content and language, but also ignores one of the eight key principles put forward by Genesee and Hamayan (2016, pp. 43-45), according to whom "the first language can be a useful tool for learning the additional language and new academic knowledge and skills".

In so doing, CLIL would endorse "a monolingual view of multilingualism" (Cenoz \& Gorter, 2017, p. 310), based on a number of monolingual ideologies, among which "native-speakerism", "the target language only"; or, the "one language at a time" rules have been enlisted (Lin \& He, 2017, p. 237). Such monolingual paradigm in language education is nurtured by traditional instructional assumptions like the interference fallacy and its corollary, the principle of language separation, which has been referred to as "the two solitudes assumption" (Cummins, 2008, p. 65) or as "multilingualism through parallel monolingualisms" (Lin, 2015, p. 75). The language separation principle, in advocating for the exclusive use of the target language as medium of instruction (henceforth, MOI), denies the role of the first language or L1 as a comprehensible input strategy (Lin, 2015). Such monolingual assumptions, exposed by Lin (2015, p. 76) as true "pedagogical straitjackets", are contradicted, first, by the reality of multilingual classroom interactions in CLIL settings (see Pavón \& Ramos, 2018; or, Lin \& He, 2017) and, most importantly, by the increasing adoption of translanguaging as a pedagogical tool to escape them (Cenoz \& Gorter, 2017; Lin \& He, 2017; San Isidro, 2018).

Despite this emphasis on the language outcomes of CLIL, though, a number of scholars at the forefront of this teaching approach have claimed that both content and language are equally important and "have a joint role" (Marsh, 2002, p. 58), that "CLIL advocates a 50:50/Content:Language CLIL-equilibrium" (Ting, 2010, p. 3), or that "it is content that determines the learning route" (Coyle, 2005, pp. 5-6). However, in practice, a balance between language and content instruction is neither easily conceived nor smoothly achieved (Cenoz et al., 2014). Actually, some of the most critical opinions against CLIL, voiced in studies published in languages other than English reported by Dalton-Puffer (2011), state that English is an obstacle when used as a MOI in content subjects. In turn, both parents and teachers often fear that students' limited understanding of a language other than their first will result in reduced academic achievement or simplified curricula (Dalton-Puffer, 2011). This subject-language relationship is also one of the points in dispute between those who align CLIL with Content-based instruction or CBI (see Cenoz et al., 2014, Cenoz, 2015; Genesee, 2008; Paran, 2013; or, Ruiz de Zarobe, 2008) and those who underscore their dissimilarities with immersion (see Coyle, 2008; Dalton-Puffer et al., 2014; Lasagabaster, 2015; Lasagabaster \& Sierra, 2010, for further discussion) and acknowledge that, more often than not, CLIL means CEIL, or Content-and-English integrated learning (see Maljers et al., 2007).

Regardless whether CLIL is proposed as an umbrella term for CBI or the other way round, what policy-makers and most education experts seem to agree with is in placing CLIL among those programs that should aim at "multilingualism and multiliteracy" (Cenoz \& Gorter, 2015, p. 2). However, according to Coyle's 4Cs framework (1999), CLIL is not only about bilingual or multilingual education but also about content, cognition and culture. As she once put it (Coyle, 2008, p. 103),

The 4Cs framework for CLIL starts with content (such as subject matter, themes, cross-curricular approaches) and focuses on the interrelationship between content (subject matter) communication (language), cognition (thinking) and culture (awareness of self and 'otherness') to build on the synergies of integrating learning (content and cognition) and language learning (communication and cultures).

The key terms here are interrelationship and integration, which is what makes CLIL an educational approach rather than a simple methodology (Marsh et al., 2010; Pérez-Vidal, 2015; San Isidro, 2018). An educational 
approach embracing a cluster of additional and very ambitious aims that Dalton-Puffer and Smit (2013, p. 554) have related to either "the quality of learning (motivation, self-confidence, deeper processing, cognitive advantages)"; or, to "the quality of teaching [...] (learner autonomy, inquiry based-teaching, interactivity)". From that holistic perspective, the ultimate goal of CLIL would be improving general education (Baetens-Beardsmore, 2001; Coyle, 2008). To that end, CLIL practices cannot adopt traditional educational approaches to both content and language instruction but change the "centredness" of classroom teaching in favour of more student-centred and more "thinking-centred" methodologies (Pavón \& Ellison, 2013, p. 73-74). As these authors (2013, p. 72) put it, "it would not be effective to teach the same content, the same way, with another language". Quality CLIL calls for innovative pedagogies, for a "new didactics" (de Bot, 2002, p. 32). Unfortunately, an agreement about what this "new didactics" should consist of is still missing (Van Kampen et al., 2017, p. 2).

The lack of a unified theory for CLIL makes it difficult to decide on a common research agenda, on clear implementation guidelines or on how teacher education provision should be. But, for CLIL understood as an educational model (Dalton-Puffer, 2011, p. 182) to succeed, improving teacher training is a must (Coyle, 2008). In Pavón and Rubio's words (2010, p. 48), prospective CLIL teachers will be "forced" to depart from a teaching system based on what they describe as "the transmission of information" by means of a lecture format, to adopt a system that gives preference to "the understanding and assimilation of contents based on heuristic activity and discovery". In brief, then, CLIL would have the potential for changing learning and teaching processes (Coonan, 2007).

\subsection{CLIL Training and Teachers' Beliefs}

A broadly felt need for better equipped CLIL practitioners is attested, on the one hand, by several proposals on the ideal CLIL teacher profile in Europe (e.g. Bertaux et al., 2010; Hansen-Pauly et al., 2009; Kelly et al., 2004; Marsh et al., 2010) or in Spain (e.g. Lorenzo et al., 2011; Pavón \& Ellison, 2013); and, on the other hand, by a number of recent studies whose aim is to identify CLIL teachers' training needs (see Pérez Cañado, 2018, for an overview). More specifically, Pérez Cañado's survey research on 241 in-service teachers across Europe and/or on 307 ones in the Spanish monolingual communities of Andalusia, Extremadura and the Canary Islands (2016b, 2017, respectively) point to the persistence of "main lacunae" in teacher training for CLIL that should be addressed (Pérez Cañado, 2016b, p. 274). Thus, even though some progress has been made to upgrade what she presents as the seven core CLIL teacher competences -i.e. (i) linguistic, (ii) pedagogical, (iii) scientific knowledge, (iv) organizational, (v) interpersonal, (vi) collaborative; and, (vii) reflective and developmental competences- (Pérez Cañado, 2017; 2018), all of these competences ought to be further entrenched.

Of particular interest for the purpose of the present paper are the following outcomes from Pérez Cañado's European survey (2016b) with respect to the variables nationality, type of teacher, teaching level and linguistic competence of the participants polled. First, in most competences, Spanish practitioners are behind their European and Latin American counterparts. Thus, while Eastern and Central European preservice teachers excel in their scientific knowledge about the theoretical tenets of CLIL (Pérez Cañado, 2018), Latin American teachers are better in student-centred methodologies, project-based language learning or collaborative teaching. Second, in comparison with language-trained teachers, content-trained ones show the lowest levels in linguistic and intercultural competences. Third, Infant and Primary teachers' linguistic and intercultural competences are equally wanting. Last but not least, it has to be noted that higher language level cannot be always equated with a greater knowledge of student-centred methodologies. Actually, it is those respondents with an L1 level the ones who say to be more familiar with cooperative student learning.

In view of her findings, Pérez Cañado (2018) calls for improving both initial and ongoing bilingual teacher training in Spain, at graduate and undergraduate levels. Accordingly, she suggests five lines of action that go from itineraries and internship periods in current undergraduate degrees to newly designed bilingual degrees or whole master degrees. Even if some of her proposals are already being implemented in a number of Spanish universities, nowadays, tertiary pre-service CLIL instruction is still exceptional and concentrated in few credits in most degrees (García Puente, 2015). Many Spanish subject teachers in Infant and Primary Education, who seem to be those practitioners whose professional formation is most unsatisfactory, are trained outside universities when they have already concluded their higher education. As a result, their CLIL training is reduced to improving their proficiency level in the target language at Official School of Languages or to attending seminars about didactic skills offered by teachers' associations like CEFIRE (Delicado \& Pavón, 2015; García Puente, 2015). While CLIL provision gains in depth and extension, in line with the actions proposed by Pérez Cañado, it seems relevant to analyse how effective current undergraduate university training on CLIL foundations is. Making the most of these courses on CLIL involves taking into consideration teacher cognition because of the impact it may have on how teacher trainees benefit from their education. 
Teacher cognition is an umbrella term in educational research that refers to teachers' mental lives and, thus, includes the beliefs held by teachers about learning and teaching practices. Borg $(2003$, p. 82) describes teacher cognition as "beliefs, knowledge, theories, attitudes, images, assumptions, metaphors, conceptions and perspectives about teaching, teachers, learning, students, subject matter, curricula, materials, instructional activities and self". In particular, beliefs are characterised as "propositions individuals consider to be true and which are often tacit, have a strong evaluative and affective content, provide a basis for action, and are resistant to change" (Borg, 2011, p. 370). Language teacher cognition started to gain momentum in the late 1980s and early 1990s when teachers' beliefs were found to have a significant impact on how teachers actually behaved in the classroom (e.g. Woods, 1996; for further discussion on the interaction between beliefs and practices, see Basturkmen, 2012). Furthermore, Johnson (1994, p. 439) outlines that insomuch as teachers' beliefs affect perception and judgement, they are not only important to understand classroom practices but also to improve teacher education programmes. Preservice teachers' beliefs can be seen as obstacles to teacher training (Joram \& Gabriele, 1998) whenever they are not aligned with the content of a program (Richards, 1998). This is why, in Donaghue's words (2003, p. 344), prospective teachers' beliefs "need to be uncovered" and taken into account when a teaching course is designed. Otherwise, teacher professional growth might suffer.

By and large, it is acknowledged that pre-service teacher training is mediated by student teachers' beliefs and prior knowledge. Still, the exact nature of beliefs and how they differ from previous knowledge has proven to be an elusive matter (Calderhead, 1996). In an attempt to tackle this definitional challenge, Pajares (1992, p. 311) argues that belief systems are more difficult to change than knowledge systems because "it is not argument or reasons that alters them". This is so, possibly, because, as Richardson's (1996) definition remarks, beliefs are a set of views, perceptions or propositions felt by a person to be true. Actually, Kagan maintains that "candidates tend to use the information provided in coursework to confirm rather than confront and correct their pre-existing beliefs" (1992, p. 154). Hence, no matter how teachers' beliefs are profiled, there seems to be a general agreement, on the one hand, about their notorious resistance to be modified (e.g. Borg, 2011; or, Kagan, 1992, to name but a few); and, on the other hand, about the sources they derive from. Personality (Donaghue, 2003) schooling (Pajares, 1992) or past learning experience (Schulman, 1987) has been put forward as factors influencing teacher cognition (for a summary, see Borg, 2003, p. 82). In brief, then, the role played by initial teacher training programmes may be crucial for reshaping novice teachers' preconceptions when they are not in accordance to teacher professional development and need, borrowing de Courcy's (2007) term, "disrupting". CLIL practitioners are not an exception and, as Bullough (1991, p. 43) contends, teacher trainers should not ignore the impact of student teachers' beliefs, understood as the filter, or the glasses (Haukås, 2018, p. 344), through which the latter see their education.

\subsection{Teachers'Beliefs in CLIL}

A number of recent studies in Europe have already investigated teachers' beliefs in CLIL. The main focus has been placed on perceptions and/or judgments of teaching and learning experiences with actual CLIL programs in several European countries like Austria (e.g. Wegner, 2012; Hüttner et al., 2013), Estonia (e.g. Mehisto \& Asser, 2007), Finland (e.g. Bovellan, 2014; Moate, 2011), Germany (e.g. Bonnet \& Breidbach, 2017; Massler, 2012; Viebrock, 2012), Ireland (e.g. Ceallaigh et al., 2017), Italy (e.g. Infante et al., 2009), Spain (e.g. Aguilar \& Rodríguez, 2012; Dafouz et al., 2007; Doiz \& Lasagabaster, 2017; Lancaster, 2016; Lova Mellado et al., 2013; Méndez García, 2012; Moliner, 2013; Pladevall-Ballester, 2014; Pena Díaz \& Porto Requejo, 2008 Querol-Julián et al., 2015; Travé González, 2013, 2016; Travé González \& Soto Rosales, 2014), the Netherlands (Denman et al., 2013; van Kampen et al., 2018); or, the United Kingdom (Hunt, 2011). A transnational comparative perspective has been also pursued with data from the Basque Country and Friesland (Arocena Egaña et al., 2015), Greece and Cyprus (Griva et al., 2014), Austria, Finland and Spain (Skinnari \& Bovellan, 2016); or, Austria, Finland, Spain and the United Kingdom (Dafouz et al., 2016). Many of the aforementioned studies, though, have explored experienced teachers' opinions and views on the effects of CLIL at secondary and tertiary levels.

Regarding Primary Education, research done to date (i) has been centred on in-service teachers and what may be called their post-CLIL beliefs (e.g. Bovellan, 2014; Ceallaigh et al., 2017; Infante et al., 2009; Massler, 2012; Mehisto \& Asser, 2007; Pladevall-Ballester, 2015, inter alia); (ii) deals with EFL teachers' pre-CLIL beliefs (e.g. Griva et al., 2014); or, (iii) has been mostly carried out in monolingual communities such as Madrid or Andalusia in Spain, where the target language, mainly English, is learnt as a second language (for a comprehensive survey on studies based in Andalusia, see Milla Lara \& Casas Pedrosa, 2018, pp. 162-165). Yet, to the best of our knowledge, little research has been conducted to look into novice subject teachers' beliefs prior to CLIL implementation, even though content-trained teachers are the ones who usually teach in "prototypical" CLIL programmes (Cenoz, 2015, p. 19). Controlled studies linking pre-service training and teacher cognition are also 
thin on the ground, because of the difficulty in determining the actual training experienced by prospective teachers. Actually, as far as we know, the impact of tertiary instruction in a multilingual setting has been only analysed by Escobar Urmeneta (2013) by means of a case study in a Master's degree for secondary language teachers in Barcelona. We may safely conclude, then, that the effect of undergraduate courses on pre-service subject teachers' beliefs in CLIL has not received to date much empirical attention.

\subsection{Aims and Research Questions}

Despite the growing number of recently published studies on CLIL practitioners' experiences reported above, we still know little about, borrowing Pavón and Méndez' words (2017, p. 240), "professed" in comparison with "enacted" beliefs. Inasmuch as teacher cognition is not only a guide for classroom behaviour but also a guide for thought (Borg, 2001), teachers' overall attitude to CLIL and their willingness to face the challenges this teaching approach entails (i.e. teacher investment in Bonnet \& Breidbach's 2017 study) may be connected with how they understand its aims and key language principles. In that vein, teacher investment in CLIL seems to be highly dependant on teachers' implicit knowledge about, first, "if and how subject matter and language learning are related", namely, the twin aim of CLIL; and, second, about key language principles or "the significance they attribute to the use of the target language, and to the amount and the nature of language work" (Bonnet \& Breidbach, 2017, p. 282). Positive appraisals of CLIL have to do with teachers' awareness of the pedagogical "mind-shift" it demands (Milla Lara \& Casas Pedrosa, 2018, p. 166). Hence, pre-existing beliefs are powerful "lay theories" that need unveiling in order to pave the way for pedagogical changes like CLIL to succeed (Hüttner et al., 2013, p. 269). That is why our main interest in this study does not lie in how experienced teachers see what CLIL really does in terms of students' learning gains (for a state of the art on subject content and language outcomes of CLIL, see Ruiz de Zarobe, 2015; or, Graham et al., 2018). Rather, we intend to gain insights into what CLIL ought to do, that is, into "ideal" CLIL pedagogies (van Kampen et al., 2017). More specifically, our purpose is to discover how prospective Primary teachers construct CLIL in bilingual communities, where English is learnt as an additional language. In accordance to the main gaps in current research noted in the previous section, the aim of the present paper is twofold. On the one hand, identifying Primary subject teachers' pre-CLIL beliefs about the benefits of this teaching approach in relation to its aims and language use principles. On the other hand, ascertaining the impact of tertiary instruction by means of a course on CLIL and through CLIL for $3^{\text {rd }}$ year undergraduates in Primary Education.

In order to fulfil these objectives, we have formulated the following research questions:

RQ1. Are prospective subject teachers aware of the benefits of CLIL in relation to its aims and principles?

RQ2. What is the impact of initial teacher training on these beliefs?

\section{Method}

\subsection{Research Setting and Participants}

Spain is one of the few European countries where CLIL programmes have been top-down implemented (for further information about CLIL in Spain, see Lasagabaster \& Ruiz de Zarobe, 2010). We say programmes in the plural because they vary in each region or autonomous community. Thanks to this diversity of CLIL policies and practices from the above, in the Spanish meso-context, we find "many examples of CLIL in different stages of development that are applicable to contexts both within and beyond Spain" (Coyle, 2010, p. viii). Since the year 2012, when the regional government passed the so-called "decree of plurilingualism", English has been introduced as the medium of instruction for only one subject in all state-funded and charter Valencian schools, from Primary to high Secondary education. The addition of this English-medium subject (Arts \& Crafts, Physical Education or Music in most Primary schools) needs to be evaluated, borrowing Lasagabaster's words (2015, p. 23), "within an existing language ecology". This included a majority language, Spanish, and a minority one, Catalan, which already coexisted in two different school-based language models. Depending on variables such as parents' decisions or availability of bilingual programmes, some Valencian children learnt Spanish as the main school language, while others went through Catalan-medium education.

Participants were 110 undergraduate students enrolled in a four-year Primary teacher education programme at a medium-sized state university in the Valencian Community (Spain). As is usually the case amongst these professionals, the typical student was a female $(75 \%, n=76)$, in her early 20 s (mean age of 20 years and 7 months). Regarding mother tongues, 59 subjects had Spanish as their reported L1; 47, Catalan; and, 4, Romanian. Although all the subjects can be classified as bilinguals in Spanish/Catalan or Spanish/Romanian, only 5 subjects made an active use of Catalan beyond the private sphere. With respect to their proficiency level in English, most were elementary students, with only $20 \%(\mathrm{n}=22)$ of intermediate learners. None of them, thus, 
fulfilled the requirements for subject Primary teachers to become CLIL practitioners established by decree 127/2012. Those requirements were to be in possession of at least B2 of the Common European Framework of Reference for Language, along with a certificate obtained after passing either an exam organized by the regional government or a 240-hour postgraduate course on the basics of CLIL offered by Valencian Universities or by teachers' associations like CEFIRE. Additionally, participants in the study did not have previous experience as students in the CLIL programmes implemented prior to the passing of decree 127/2012 in the Valencian Community (mostly in private schools or at secondary education with subjects like Citizenship).

\subsection{Instrument, Procedure and Data Analysis}

The course "English Language Teaching" is the only compulsory subject taught through this foreign language in the Primary teacher education programme in which participants are enrolled. Although this ELT course adopts a CLIL teaching approach, CLIL as such is not dealt with until the fourth and last unit of the syllabus. Prior to this, teacher trainees are provided with literature that goes from a traditional SLA perspective to a third language acquisition one. The first three units are designed for student teachers to gain knowledge on how English is learnt with the following topics of interest: teaching/learning English as a lingua franca (from EFL to ELF), Krashen's main hypotheses on SLA; and, the role of learners' individual factors like motivation, age, and/or bilingualism. Key concepts such as Cook's multicompetence are introduced and a number of myths (e.g. the earlier the better assumption) are contrasted with the results of current research. The purpose is to present and to understand the plurilingual view according to which the goals of language education are established since the Common European Framework of Reference for Languages was enforced. Activities in the course range from the presentation of contents by means of a lecture format to class debates, small group or pair discussions and individual essays. As far as the CLIL module is concerned, participants attended a total of 12 in-class sessions that amount to 18 contact hours with the lecturer and 6 hours of students' autonomous work.

On the first session devoted to Unit 4, "An Introduction to the Principles of CLIL for the Primary Classroom", attendees were requested to elaborate an argumentative essay on "pros" and "cons" of CLIL for Primary students. With the aim of eliciting non-standardized answers, the topic of the essay was kept deliberately open to grant participants the opportunity to reply quite freely. They could also choose the language in which they prefer to answer. While $73 \%$ of the subjects $(\mathrm{n}=80)$ opted for Spanish, $19 \%(\mathrm{n}=21)$ answered in English; and, $8 \%(\mathrm{n}=9)$, in Catalan. There was no limit of space to elaborate the text, but attendees were given approximately 20 minutes to write their compositions, which were collected on the spot. A month and a half later, after having completed 18 hours of instruction on CLIL and through CLIL, a second essay on the same topic was written and delivered. This time, $77 \%$ of the subjects $(\mathrm{n}=85)$ answered in Spanish, $5 \%(\mathrm{n}=5)$ opted for English; and, $18 \%(\mathrm{n}=20)$ chose Catalan. Thus, a single-group pre-test/post-test design was used.

Data were analysed according to qualitative content analysis or QCA (see Mayring, 2014, or Schreier, 2012, for a description). QCA is a mixed-method approach that follows a thematic criterion to reduce text data in a way that is both flexible and systematic (Mayring, 2014; Schreier, 2012). In presenting features of both qualitative and quantitative research, QCA is suitable for addressing descriptive research questions like the ones guiding this study. Adopting this method allowed us to combine a concept-driven approach in the definition of the main categories in our coding frame (i.e. aims of CLIL) and a data-driven approach in the coding of the sub-categories that emerge from the data (i.e. the reasons by which the aims of CLIL can or cannot be attained). Hence, after having conducted a first coding of the data in accordance to the main theme of the essay (i.e. "pros" and "cons" of CLIL for Primary students), the following two sub-themes were identified:

(1) Learning gains and learning losses resulting from CLIL implementation

(2) Conditions for success and barriers to CLIL implementation

Due to space constraints and in line with the research questions posed, only the results belonging to the first sub-theme will be reported here. Within this first sub-theme, responses were firstly coded according to Coyle's $4 \mathrm{Cs}$ framework for the aims of CLIL, that is, in terms of learning gains (or losses) in content, communication, cognition and culture, which became the main categories in our coding frame. This deductive approach was complemented with an inductive one, resulting in the sub-categories described in Tables 1 and 2 (see the Appendix). Consistency in data analysis was checked by a senior researcher, who audited the reliability of the coding frame. Seeing that disagreements among coders were minor and could be readily solved, no coefficient of inter-coder agreement was calculated (Schreier, 2012). 


\section{Results and Discussion}

\subsection{Results and Discussion Related to Research Question 1}

The first research question targeted in this paper asks whether prospective subject teachers are aware of the benefits of CLIL in relation to its aims and language principles. According to Figure 1 below, participants show a limited understanding of the multidimensional nature of CLIL proposed by Coyle (2008) in her 4 Cs framework. Before instruction, the learning gains of CLIL were perceived by 101 out of 110 respondents as being mostly linguistic ones or closely linked to the $\mathrm{C}$ of communication. In comparison, the $\mathrm{C}$ of content $(\mathrm{n}=25)$ and/or the $\mathrm{C}$ of cognition $(\mathrm{n}=5)$ are secondary, while the $\mathrm{C}$ of culture does not exist.

\section{Benefits of CLIL (pre-test)}

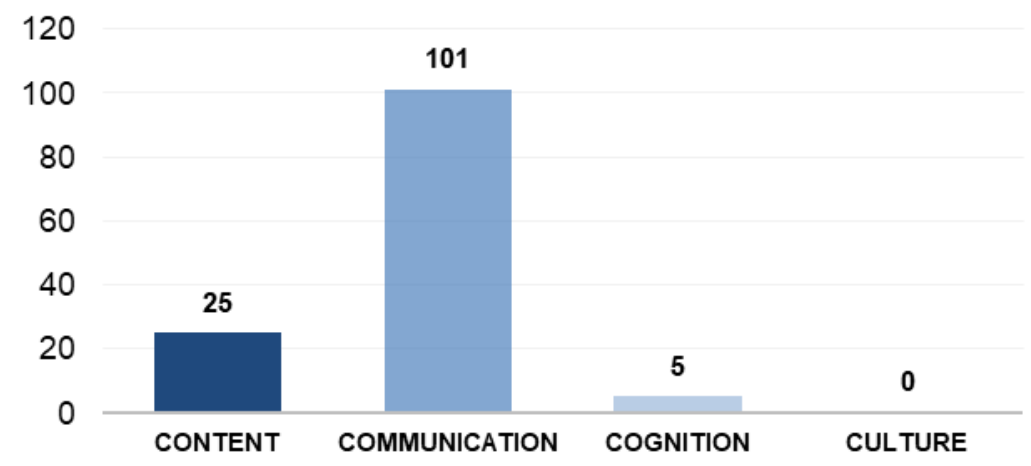

Figure 1. Benefits of CLIL according to Coyle's 4 Cs framework (pretest)

A possible explanation for this unequal perception on the main aims of CLIL might be found in Table 1 (see the Appendix), which enlists the reasons given to justify the "pros" and "cons" of implementing this teaching approach in Primary Education. Starting with the $\mathrm{C}$ of communication, the wide consensus observed in our data with respect to the positive language outcomes of CLIL, supported by $92 \%$ of Valencian novice subject teachers, contrasts with the more modest results from Griva et al.'s (2014) study on post-CLIL views, according to which $69.1 \%$ of Greek EFL teachers and only $40 \%$ of Cypriot ones agree that CLIL can promote language learning. Furthermore, $82.4 \%$ of these Greek language specialists and $62.5 \%$ of their Cypriot counterparts put forward that CLIL can negatively influence Primary students' language competence in English.

The enthusiasm of our participants regarding the linguistic side of CLIL might have derived from how they liken this ideally dual-focused educational approach (Coyle et al., 2010) to intensive exposure to the target language (Lo, 2015) or, most importantly, to immersion. Despite knowing that decree 127/2012 only establishes a subject to be taught through English, 25\% of these teachers-to-be maintain that CLIL will afford more quantity of input. As certain emphasis is also put on the quality of an exposure to English, which is said to favour unconscious learning of grammar and vocabulary by some $(\mathrm{n}=7)$, it might be argued, in line with previous literature (Dalton-Puffer \& Smit, 2007, pp. 8-10), that here pro-CLIL arguments are also based on the credit still given to Krashen's Input Hypothesis. The association of this minimal CLIL program with naturalistic language learning conditions is completed when $30 \%$ of our respondents endorse one of the slogans of this teaching approach, according to which "to use language is to learn language" (Genesee \& Hamayan, 2016, p. 41).

Thus, when attention is paid to students' output, 33 subjects assert that this is meaningful-oriented and closer to real-life usage, 13 point to a strong focus on interaction, 18 consider that learners will acquire vocabulary and expressions for everyday life communication; and, 4 claim that they will become more fluent. In so doing, our respondents are not only associating CLIL with an improved version of foreign language teaching, a trend already highlighted by many scholars (e.g. Cenoz et al., 2014, p. 357; Dalton-Puffer, 2011, p. 184; Serra, 2007, p. 582, inter alia), but end up identifying CLIL with Communicative Language Teaching itself (Dalton-Puffer \& Smith, 2007, p. 8). Contrary to the strongly grammar-based FI typical of the traditional EFL classroom, CLIL is perceived by $26 \%$ of participants as an innovative alternative thought to solve most of the shortcomings attributed to the former. More specifically, 23 respondents explain that, in contrast to mainstream English courses, CLIL is really skill-centred, while 29 of them remark that it offers useful content-specific vocabulary absent from the EFL class. 
Notably, unlike what has been reported in other contexts (e.g. Austrian upper secondary technology teachers in Hüttner et al., 2013, p. 277; or secondary CLIL practitioners in the Netherlands in van Kampen et al., 2018, p. 222), only 4 participants out of 110 construct CLIL as complementary or additional to EFL lessons. Instead, 26\% of them $(\mathrm{n}=29)$ present CLIL in terms of a replacement of EFL regular lessons, which are blamed for Spanish students' poor results in this foreign language. As one of the participants puts it, "So far the English subject in Spain hasn't helped students to succeed because children do not learn English by only doing repetitive exercises that are easily forgotten; and, thanks to CLIL, they will be able to learn useful English and develop their confidence" (S27). By the same token, S16 states: "I think that CLIL might become more useful that all the lessons received based on pure theory, because the best way for a child to learn a language is practising and listening to it and not memorizing". This optimistic outlook on the learning gains for English, harboured by a considerable amount of subjects in our sample, contrasts with the fact that there is only one respondent (S80) who underscores that CLIL is a door to Primary students' bilingualism (Spanish/English).

More importantly, nobody explicitly mentions the idea of CLIL as a way of fostering plurilingualism, advocated by European high-level policymakers (see European Commission, 1995). Conversely, six participants express their concern about the detrimental effect of teaching content through English for Primary students' first language (s). This dread, although minoritarian, may result from having equated English as MOI in only one subject (Arts \& Crafts, Physical Education or Music in most Valencian state-run or charter Primary schools) with a strong form of immersion. As a matter of fact, S46 cautions us against extending CLIL to most content subjects for the danger this would pose to the acquisition of written and oral skills in Spanish. In turn, S41, whose first language is also Spanish, is worried about the descending results on Primary students' linguistic competence in Spanish he has read in the PISA report and has attributed to the increasing presence of English; while S60 recommends that neither Spanish nor Catalan (her mother tongue) should be neglected. It is worth noting, though, that the two subjects that do display more negative attitudes on the impact of CLIL on Primary students' first language(s), by claiming that languages should be learnt one at a time, are Romanian student teachers.

In tune with some of the most pessimistic views held by scholars, teachers and parents alike (see Dalton-Puffer 2011), objections to CLIL grow when participants' attention moves from how this teaching approach may affect Primary students' first language development to their academic achievement in a given subject-matter other than English. As previously seen in Figure 1, 23\% of respondents $(n=25)$ acknowledge that CLIL enhances more in-depth knowledge of content due to the higher attention and reflection involved in order to understand a foreign language that is not the pupils' first. A few $(\mathrm{n}=2)$ also note that teaching through English means adopting a cross-curricular approach that enriches subject-matter teaching. Yet, many more $(n=65)$ fear that the introduction of English as the only MOI in content subjects will endanger non-linguistic content. With a percentage of $59 \%$ of the sample, our findings regarding the relationship between content and language in CLIL are in accordance with those reported by Griva et al. (2014), with $67.3 \%$ of Greek EFL teachers and 55\% of Cypriot EFL teachers stating that this teaching approach might make content based knowledge suffer.

A closer look into the reasons supporting this more critical, even sceptical stance on the effectiveness of CLIL for content learning reveals that $33 \%$ of participants $(n=36)$ in the present study think that teaching through a foreign language, which is unfamiliar for most Valencian Primary children, would limit their understanding of contents; and, $20 \%(\mathrm{n}=22)$ insist on presenting it as a time consuming process that impoverishes the mandatory curricula. Apparently, what hinders Primary students' comprehension of the subject-matter and slows down CLIL lessons is the English only rule that seems to unavoidably force the teacher to resort to longer explanations in order to avoid translating them entirely from English into to the learners' L1(s). Inasmuch 15\% of our subjects $(\mathrm{n}=17)$ describe this approach in terms of a transmissive teaching model based on lecturing, CLIL is understood here as explaining content in English (our emphasis) and, hence, the language "ends up turning into an obstacle" (S59).

Since only very few respondents propose a different approach to content-and-language teaching in CLIL, with five subjects urging to explain the most complex concepts in the children's L1 (s), two suggesting the need to implement comprehensible input techniques and just one advocating for a cross-linguistic approach including translation, we may safely conclude that an overwhelming majority of the participants in this study are unaware of Coyle (2005, pp. 5-6) appealing that "it is content that determines the learning route [...]. The emphasis is always on accessibility of language in order to learn". That is to say, by failing to acknowledge one of Genesee \& Hamayan's (2016, p. 43-45) eight key principles of CLIL, according to which "the first language can be a useful tool for learning the additional language and new academic knowledge and skills", a balance between content and language cannot be stricken and the twin aim of CLIL seems to get lost. As a result, the target language is claimed to be learnt at the expense of content and, remarkably, some participants even affirm that 
CLIL is not for content subjects (e.g. S79), but an innovative approach to be implemented "in class of english [sic] or in a talk or conversation group" (S31).

To sum up, what transpires from these results concerning RQ1 is that denying the role of the first language(s) as a comprehensible input strategy (Lin, 2015) or following the language separation principle in CLIL would not be an option for subject teacher trainees. Rather, debunking the monolingual assumptions, which scholars like Lin (2015, p. 76) has described as "pedagogical straightjackets", appears to be a requirement for this group of prospective CLIL practitioners to consider the content-language-cognition-culture aims as positive for Primary students. Otherwise, in their view, only the linguistic goal of CLIL prevails in detriment of content and cognition that become unattainable, while the cultural component is directly ignored.

\subsection{Results and Discussion Related to Research Question 2}

The second research question was posed to examine the extent to which the knowledge about the main CLIL tenets to which participants were exposed had challenged their prior beliefs presented above. In other words, RQ2 is about the impact of initial teacher training on these beliefs, for the purpose of this study is also to compare pre-service subject teachers' entry and exit point understanding of CLIL aims and language principles in an 18-hour undergraduate course on CLIL and through CLIL. This way, participants are in the position of assessing whether content, language, cognition and culture/community can be integrated in CLIL from a double perspective: as Primary teachers-to-be and as student teachers who have experimented, for the first time, the advantages and disadvantages of learning a subject-matter (i.e. English Language Teaching) through a foreign language in which most of them are beginners.

All in all, since we attempt to identify those aspects in teacher preparation programmes for CLIL that might be improved, what needs to be ascertained is the assumptions and preconceptions on the aims and language principles of this teaching approach that have proven more deeply-rooted versus those that can be regarded as more sensitive or more permeable to instruction. Following Kagan (1992, p.154), then, our aim would be to explore when candidates have used "the information provided in coursework to confirm rather than confront and correct their pre-existing beliefs". In addition, we would also like to suggest some individual factors that might explain why it is that, as Pajares once put it (1992, p. 311), "it is not argument or reasons that alters them". To that end, Figure 2 illustrates how respondents perceive the benefits of CLIL according to Coyle's 4 Cs framework after instruction.

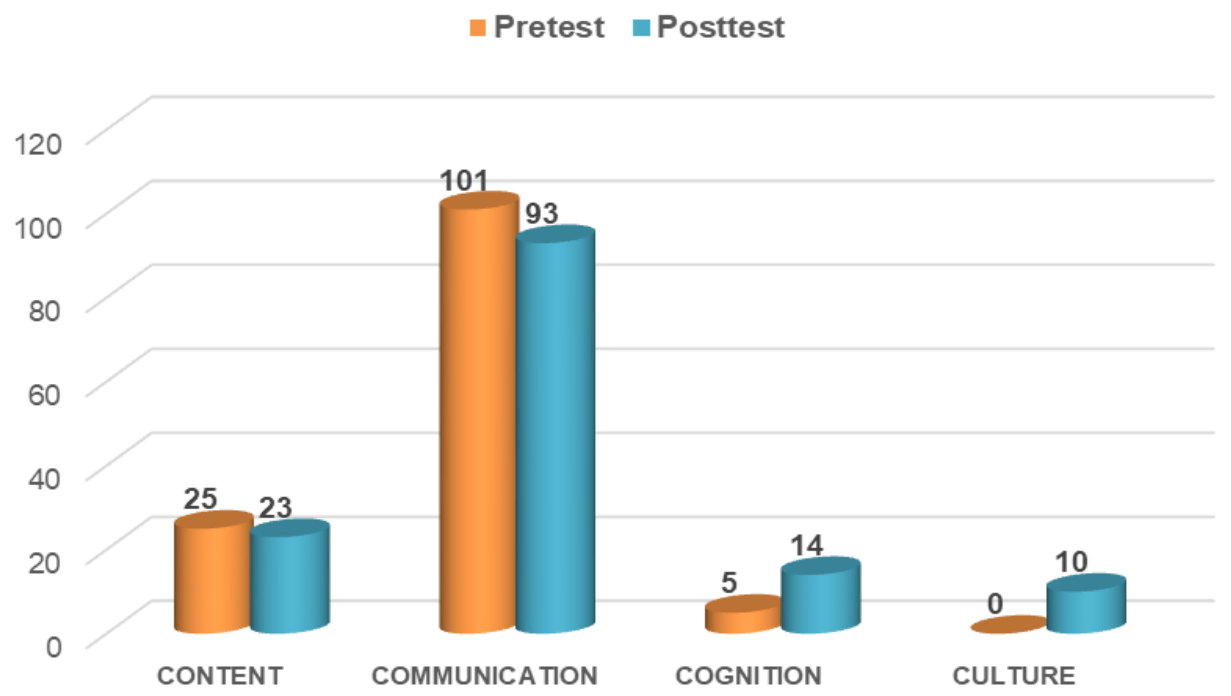

Figure 2. Impact of instruction on the benefits of CLIL according to Coyle's 4 Cs framework

Taken together, the total number of participants identifying the aims of CLIL in terms of content, communication, cognition and culture has not been dramatically altered. The bias towards the language learning gains of this teaching approach persists, even though, after instruction, the pretest figure of 101 out of 110 respondents decreases to 93. Still, this slight descent is not accompanied by an appreciable rise in the figures acknowledging the benefits of CLIL for content, cognition or culture. It is true that, in the posttest, the C of culture appears for the first time with 10 subjects referring to how CLIL fosters intercultural competence or ICC in Primary children. 
The number of student teachers who perceive that CLIL is about developing learners' cognitive skills also goes from 5 prior to instruction to 14 after it. Yet, these posttest figures are rather modest; and, most importantly, the number of subjects who think that CLIL improves content learning does decrease from 25 to 23 .

More specifically, when comparing pretest and posttest results concerning the twin aim of CLIL, that is, content and language integrated learning, Figure 3 shows that $68 \%$ of our respondents $(n=75)$ do not change their beliefs. Actually, $41 \%(n=45)$ of them maintain, both before and after instruction, that "CLIL is positive for language learning but content learning suffers", due to Primary students' limited comprehension conducive to teachers slowing down their explanations. Conversely, in the post-test, 29 subjects (26\%) think that CLIL implementation benefits both content and language learning. Since 18 of them already believed that this twin aim was attainable in the pre-test, only 11 respondents have actually changed their perception of the CLIL goals from "positive for language learning but content learning suffers" to "CLIL benefits both content and language learning". In that respect, then, our findings would be consistent with prior research in the field of teacher cognition attesting the resistance of beliefs to be modified (see Borg, 2011; or, Kagan, 1992).

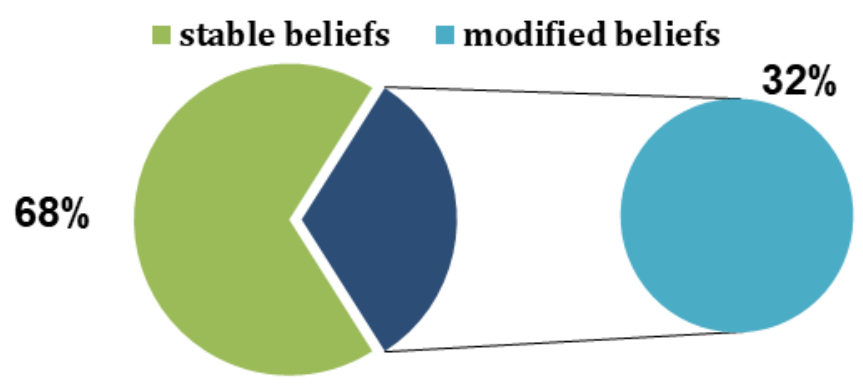

Figure 3. Impact of instruction on beliefs about the twin aim of CLIL

Some explanation about why a high percentage of participants do not seem to have made a significant improvement in their awareness of the multidimensional nature of CLIL embodied in Coyle's 4Cs framework can be sought in a pretest-posttest comparison of the reasons they give to justify the "pros" and "cons" of this teaching approach for Primary education (see Table 2 in the Appendix). The first feature of these data that warrants comment is the fact that Krashen's Input Hypothesis, far from losing influence, has been reinforced. While the percentage of respondents stating that CLIL provides more quantity of input has slightly descended from $25 \%(\mathrm{n}=27)$ to $19 \%(\mathrm{n}=21)$, the number of those who emphasize that the quality of input improves in CLIL has raised from $8(7 \%)$ to $24(22 \%)$. When considering that better input favours unconscious learning of grammar and vocabulary, most of these participants claim that, in CLIL lessons, Primary students will acquire English "in a natural way".

Such clear resonance of Krashen and Terrell's (1983) The Natural Approach is particularly interesting for a couple of reasons. First, because teaching only one subject like Arts \& Crafts, Physical Education or Music through English, which is the minimal CLIL program passed in decree 127/2012, should not be equated with a strong form of immersion as it cannot ensure an intensive exposure to the target language in terms of contact hours. Second, because discussions of Krashen's main hypotheses on SLA in the second unit of the course had already pointed out the shortcomings of "the natural method" when it is applied to EFL instructional settings. All in all, the same faith in that this Valencian CLIL program will provide naturalistic language learning conditions ideal for authentic meaningful oriented interaction is declared by $39 \%$ of participants (ten more than in the pretest) when considering, as S49 does, that "[...] when teaching Arts \& Crafts or P.E. in English we will put the child in a situation where $\mathrm{s} / \mathrm{he}$ is immersed in this foreign language, giving them the chance to practise it in a natural context, instead of trying to create imaginary situations like the ones in a regular English lesson". No wonder, then, that the respondents who see CLIL as an alternative to mainstream English still outperform those who consider that both are complementary in a posttest proportion of 26 to 4 versus 29 to 4 in the pretest.

Regarding their appraisal of the M-factor, that is, as far as plurilingualism as the main goal of CLIL is concerned, the number of participants who think that CLIL will afford Primary students to become bilingual (Spanish/English) goes from one to four. Besides, eight respondents link CLIL with plurilingualism, although S60, for instance, defines it in terms of "mastery of different languages". As shown in a previous work with a similar sample of Valencian Infant and Primary subject teachers-to-be (Portolés \& Martí, 2018), this maximal 
definition of what being multilingual means is rather extended among student teachers and can be attributed to the prevalence of the native speaker construct as the yardstick to measure proficiency in any language (for a discussion of the native-speaker myth, see Davies, 2003; or Llurda, 2009, 2016). The presence of other instances of monolingual ideologies in the form of "the interference fallacy" can be also traced in the worries of ten subjects (four more than in the pretest) about the potential harmful effect of CLIL on the students' L1(s). Their shared concerns are outspoken by S105 when she questions the convenience of introducing English as a MOI when the L1 of young learners is not fully consolidated. The fear of Primary children mixing languages, voiced by Romanian students in the pretest, is mostly supported after instruction by participants who are unsure about their condition of bilinguals in Spanish/ Catalan because, even if they understand the minority language (i.e. Catalan), only make an active use of the majority one (i.e. Spanish).

However, the monolingual principle that seems to prevail among a higher percentage of participants and greatly hampers their full understanding of CLIL is the target language only rule, which has remained mostly unchallenged. Thus, the strategies that would result in a truly multilingual approach to CLIL, where students' L1(s) are, in Lin's words (2015, p. 81) neither "normalized" nor "condemned", are only put forward by seven respondents recommending comprehensible input techniques (e.g. use of visual aids), seven supporting a cross-linguistic approach that includes translanguaging and the use of cognates; and two proposing a moderate use of translation. This little awareness of the linguistic techniques that would make possible for lower proficient students to understand the target language is accompanied by a minority of participants $(n=6)$ who claim that implementing CLIL calls for changing the way content is taught by means of anchoring, scaffolding or cooperative learning. S62 illustrates this view when writing in English that: "After I know a little more of CLIL, I have a different opinion. I think that CLIL it [sic] is possible to use in all subjects. Of course, if the teacher use [sic] technics to help her students to understand the lesson such as, anchoring, scaffolding, etc. To conclude, [...] I can see a different way to [sic] teach and it is possible that if one day I can teach I use [sic] this methodology because I know that [sic] is usefull [sic]".

Yet, this acceptance of CLIL as an innovative approach to both language and content is not representative of the whole sample. For one, because $45 \%$ of participants $(n=49)$ still think that the subject matter will be poorly covered due to students' limited understanding $(n=22)$ or due to the teacher's slower delivery rate $(n=20)$. Second, because 16 respondents -only one fewer than in the pretest- explicitly state the idea that CLIL is about the transmission of knowledge in a foreign language. Last but not least, because only two subjects refer to the need of developing students' critical and creative thinking.

\section{Concluding Remarks}

The present paper sets out to look into the reception of a mandatory school-based CLIL program in one of the bilingual regions of Spain, the Valencian Community, where English is learnt as an additional language. The aims guiding this study are two: analysing novice subject teachers' beliefs about the aims and language principles of CLIL for Primary education (i.e. RQ1); and, finding out how their beliefs evolve through an initial ELT course (i.e. RQ2). When establishing these centres of interest, we intended to deal with two aspects underexplored in the previous literature, namely, pre-CLIL beliefs and the impact of formal education on them. Our assumption that prospective CLIL teachers' perception of this teaching approach as salutary or detrimental would depend on their understanding of its aims and language principles seems to be confirmed by the results related to the first research question (i.e. whether prospective subject teachers are aware of the benefits of CLIL in relation to its aims and principles). Participants are not generally conscious of the added value of CLIL in terms of subject knowledge, cognition and culture, embodied in Coyle's 4Cs framework. There is a common agreement on the advantages CLIL entails for foreign language learning but subject knowledge is perceived to weaken, and little or no consideration is given to students' cognitive and intercultural development.

This staunch conviction on the language gains of CLIL not only overtakes Greek and Cypriot EFL teachers in enthusiasm (Griva et al.'s, 2014) but also reduces the goals of CLIL to its language side, interpreting it as an innovative approach to ELT. In so doing, our respondents present CLIL as a replacement for the EFL subject, rather than as a complement to it, as Austrian and Dutch secondary CLIL teachers do (Hüttner et al., 2013; Kampen et al., 2018). Two variables may be at the heart of this group of Valencian teachers-to-be associating English mainstream lessons with the pitfalls of grammar translation (Lin, 2015), while CLIL is linked to naturalistic language learning and the promises of acquiring English effectively and "painlessly" (Dalton-Puffer, 2011, p. 193). First, their profile as subject teachers with no specific training on how languages are learnt prior to instruction; and, second, the dissatisfaction with EFL teaching derived from their own story as language learners and their low proficiency level in this foreign language. Conversely, neither the inclusion of the M-factor in the contents of the ELT course nor the experience of part of the sample with multiple language acquisition appear to 
have been sufficient for most participants to understand CLIL as a way to multilingualism. In fact, a great deal of the arguments against CLIL they voice has to do with the persistence of a set of monolingual ideologies of teaching through a foreign language, which has proven resistant to change.

Precisely, the second research question was formulated to ascertain whether assumptions of this kind are sensitive to instruction. The answer is that, on the whole, the impact of instruction has proven to be scant. The reasons for this finding might be sought in some unfavourable teaching conditions like the short length of the instructional treatment -18 hours within an only course on English Language Teaching in the whole Primary Education study plan-, or a large class size with 90 student teachers per session conducive to lecturing on CLIL. All in all, and contrary to what happens in other Spanish monolingual settings like Andalusia (see Méndez \& Pavón, 2012), the fact that only a minority of our subjects start welcoming the potential benefits of adopting a cross-linguistic approach to CLIL in the posttest has to be noted. When pre-service teachers' beliefs are based on societal tendencies, incessantly advertised in the mass media, like those supporting the miracles of "the natural method" and some of the monolingual principles it upholds (e.g. "native-speakerism", "the target language only"; or, the "one language at a time"), the effects of instruction are rather modest.

Last but not least, this study is subject to a number of limitations and further research is required before anything more that tentative conclusions can be drawn. The small sample size means that we cannot generalize the outcomes to the broader population of CLIL teachers-to-be in the Valencian Community, in Spain; or, internationally. There is also a data triangulation deficit that may be solved in the near future by factoring in other data collection sources such as interviewing respondents. Still, we hope that the findings presented here may have helped at least in two respects. First, to identify some aspects that are relevant in understanding the teachers' position and disposition regarding the implementation of quality CLIL in Spanish Primary education. Second, to provide some useful indicators as to how teacher education programmes might be improved. The outcome of this study suggest that more than attendance is needed if pre-service subject teachers' prejudices and misunderstandings about the aims and language principles of CLIL can be changed into more informed and realistic perspectives. Without understanding that CLIL is "a type of instruction that fuses the best of subject matter and language teaching pedagogies" (Morton, 2010, p. 27) or by failing to see that multilingualism cannot be boosted without adopting a multilingual focus to additional language learning, quality CLIL will not be possible and the pedagogical potential of this teaching approach to content, language, cognition and culture will be irremediably wasted. We concur, then, with Wolff (2012, p. 107) when he claims that "CLIL teacher education, if taken seriously, constitutes a fundamental part of all teacher education, that every teacher should be educated, in fact, as a CLIL teacher".

\section{Acknowledgments}

As members of the LAELA (Lingüística Aplicada a l'Ensenyament de la Llengua Anglesa) research group at Universitat Jaume I (Castellón, Spain), we would like to acknowledge that this study is part of a research project funded by (a) the Spanish Ministerio de Economía y Competitividad (FFI2016-78584-P), (b) the Universitat Jaume I (P1·1B2015-20), and (c) Projectes d'Innovació Educativa de la Unitat de Suport Educatiu 3457/17.

\section{References}

Aguilar M., \& Rodríguez, R. (2012). Lecturer and student perceptions on CLIL Spanish university. International Journal of Bilingual Education and Bilingualism, 15(2), 183-197. https://doi.org/10.1080/13670050.201 1.615906

Arocena Egaña, E., Cenoz, J., \& Gorter, D. (2015). Teachers' beliefs in multilingual education in the Basque country and in Friesland. Journal of Immersion and Content-Based Language Education, 3(2), 169-193. https://doi.org/10.1075/jicb.3.2.01aro

Basturkmen, H. (2012). Review of research in the correspondence between language teachers' stated beliefs and practices. System, 40(2), 282-295. https://doi.org/10.1016/j.system.2012.05.001

Baetens-Beardsmore, H. (2001). Foreword: The past decade and the next millenium. In D. Marsh, A. Maljers, \& A. Hartiala (Eds.), Profiling European CLIL Classrooms (pp. 10-11). UNICOM: University of Jyväskylä \& European Platform for Dutch Education.

Bertaux, P., C. M. Coonan, M. J. Frigols, \& P. Mehisto (2010). The CLIL Teacher's Competence Grid. Retrieved from http://ccll-eu.eu/cms02/fileadmin/daten/Dateien/Konferenzen/THE_CLIL_TEACHER_latest_version. pdf

Bovellan, E. (2014). Teachers' Beliefs About Learning and Language as Reflected in Their Views of Teaching Materials for Content and Language Integrated Learning (CLIL). Finland: University of Jyväskylä. 
Bonnet, A., \& Breidbach, S. (2017). CLIL teachers' professionalization. Between explicit knowledge and profesional identity. In A. Llinares, \& T. Morton (Eds.), Applied Linguistics Perspectives on CLIL (pp. 269-285. Amsterdam: John Benjamins. https://doi.org/10.1075/11lt.47.16bon

Borg, S. (2001). Self-perception and practice in teaching grammar. ELT Journal, 55(1), 21-29. https://doi.org/10.1093/elt/55.1.21

Borg, S. (2003). Teacher cognition in language teaching: A review of research on what language teachers think, know, believe and do. Language Teaching, 36(2), 81-109. https://doi.org/10.1017/S02614448030019033

Borg, S. (2011). The impact of in-service teacher education on language teachers' beliefs. System, 39(3), 370-380.

Bullough, R. V. (1991). Exploring Personal Teaching Metaphors in Preservice Teacher Education. Journal of Teacher Education, 42(1), 43-51. https://doi.org/10.1177/002248719104200107

Calderhead, J. (1996). Teachers: Beliefs and Knowledge. In D. C. Berliner, \& R. C. Calfee (Eds.), Handbook of Educational Psychology (pp. 709-725). New York: McMillan.

Cenoz, J. (2015). Content-based instruction and content and language integrated learning: the same or different? Language, Culture and Curriculum, 28(1), 8-24. https://doi.org/10.1080/07908318.2014.1000922

Cenoz, J., \& Gorter, D. (2015). Towards a holistic approach in the study of multilingual education. In J. Cenoz, \& D. Gorter (Eds.), Multilingual Education: Between Language Learning and Translanguaging (pp. 2-15). Cambridge: Cambridge University Press.

Cenoz, J. \& Gorter, D. (2017). Translanguaging as a Pedagogical Tool in Multilingual Education. In J. Cenoz, D. Gorter, \& S. May (Eds.), Language Awareness and Multilingualism (3rd ed., pp. 309-321). Cham: Springer. https://doi.org/10.1007/978-3-319-02325-0

Cenoz, J., Genesee, F., \& Gorter, D. (2014). Critical analysis of CLIL: Taking stock and looking forward. Applied Linguistics, 35(3), 356-369. https://doi.org/10.1093/applin/amt011

Coonan, C. M. (2007). Insider views of the CLIL class through teacher self-observation-introspection. International Journal of Bilingual Education and Bilingualism, 10(5), 625-646. https://doi.org/10.216 7/beb463.0

Coyle, D. (1999). Theory and planning for effective classrooms: supporting students in content and language integrated learning contexts. In J. Masih (Ed.), Learning Through a Foreign Language (pp.46-62). London: CILT.

Coyle, D. (2005). CLIL planning tools for teachers. 4Cs curriculum guidance. 3As lesson planning tool. Matrix audit tool for tasks \& materials. Nottingham: University of Nottingham.

Coyle, D. (2008). CLIL - A pedagogical approach from the European perspective. In N. Van Dusen-Scholl, \& N. H. Hornberger (Eds.), Encyclopedia of Language and Education (2nd ed., Vol. 4, pp. 97-112). Berlin: Springer. https://doi.org/10.1007/978-0-387-30424-3_92

Coyle, D. (2010). Foreword. In D. Lasagabaster, \& Y. Ruiz de Zarobe (Eds.), CLIL in Spain: Implementation, results and teacher training (pp. vii-viii). Newcastle: Cambridge Scholars Publishing. https://doi.org/10.1 4797/mdcj-6-3-1

Coyle, D., Hood, P., \& Marsh, D. (2010). CLIL. Content and Language Integrated Learning. Cambridge: Cambridge University Press.

Cummins, J. (2008). Teaching for transfer: Challenging the two solitudes assumption in bilingual education. In J. Cummins, \& N. Hornberger (Eds.) Encyclopedia of language and education. Vol. 5 Bilingual Education (pp. 65-75). New York: Springer.

Davies, A. (2003). The native speaker: Myth and reality. Bristol: Multilingual Matters.

Dafouz, E., B. Nuñez, C. Sancho, \& D. Foran (2007). Integrating CLIL at the Tertiary Level: Teachers' and Students' Reactions. In D. Wolff, \& D. Marsh (Eds.), Diverse contexts, converging goals. Content and Language Integrated learning in Europe (pp. 91-102). Frankfurt: Peter Lang.

Dafouz, E., Hüttner, J., \& Smit, U. (2016). University Teachers' Beliefs of Language and Content Integration in English-Medium Education in Multilingual University Settings. In T. Nikula, E. Dafouz, P. Moore, \& U. Smit (Eds.), Conceptualising integration in CLIL and multilingual education (pp. 123-143). Bristol: Multilingual Matters. https://doi.org/10.21832/9781783096145-009 
Dalton-Puffer, C. (2011). Content-and-Language integrated Learning: From Practice to Principles? Annual Review of Applied Linguistics, 31, 182-204. https://doi.org/10.1017/S0267190511000092

Dalton-Puffer, C., \& Smit, U. (2007). Introduction. In C. Dalton-Puffer, \& U. Smit (Eds.), Empirical Perspectives on CLIL Classroom Discourse (pp. 7-23). Frankfurt: Peter Lang.

Dalton-Puffer, C., \& Smit, U. (2013). Content and Language Integrated Learning: A research agenda. Language Teaching, 46(4), 545-559. https://doi.org/10.1017/S0261444813000256

Dalton-Puffer, C., Nikula, T., \& Smit, U. (2010). Language Use and Language Learning in CLIL Classrooms. Amsterdam: John Benjamins. https://doi.org/10.1075/aals.7

Dalton-Puffer, C., Llinares, A., Lorenzo, F., \& Nikula, T. (2014). "You Can Stand Under My Umbrella": Immersion, CLIL and Bilingual Education. A Response to Cenoz, Genesee \& Gorter (2013). Applied Linguistics, 35(2), 213-218. https://doi.org/10.1093/applin/amu010

de Bot, K. (2002). Relevance of CLIL to the European commission's language learning objectives. In D. Marsh (Ed.), CLIL/EMILE-The European Dimension: Actions, Trends and Foresight Potential. Jyväskyla: University of Jyväskylä.

de Courcy, M. (2007). Disrupting preconceptions: challenges to pre-service teachers' beliefs about ESL children. Journal of Multilingual and Multicultural development, 28(3), 188-203. https://doi.org/10.2167/jmmd454.0

de Graaff, R., Koopman, G. J., Anikina, Y., \& Westhoff, G. (2007). An Observation Tool for Effective L2 Pedagogy in Content and Language Integrated Learning (CLIL). International Journal of Bilingual Education and Bilingualism, 10(5), 603-624. https://doi.org/10.2167/beb462.0

Delicado Puerto, G., \& V. Pavón Vázquez (2015). La implantación de titulaciones bilingües en la Educación Superior: El caso de la formación didáctica del profesorado bilingüe de primaria en la Universidad de Extremadura. Educación y Futuro, 32, 35-63.

Denman, J., Tanner, R., \& Graaff, R. de (2013). CLIL in junior vocational secondary education: Challenges and opportunities for teaching and learning. International Journal of Bilingual Education and Bilingualism, 16(3), 285-300. https://doi.org/10.1080/13670050.2013.777386

Doiz, A., \& Lasagabaster, D. (2017). Management Teams and Teaching Staff: Do They Share the Same Beliefs About Obligatory CLIL Programmes and the Use of the L1? Language and Education, 31(2), 93-109. https://doi.org/10.1080/09500782.2017.1290102

Donaghue, H. (2003). An instrument to elicit teachers' beliefs and assumptions. ELT Journal, 57(4), 344-355. https://doi.org/10.1093/elt/57.4.3444

García Puente, R. (2015). CLIL Teacher Training in Europe. Educación y Futuro, 32, 35-63.

Escobar Urmeneta, C. (2013). Learning to become a CLIL teacher: teaching, reflection and professional development. International Journal of Bilingual Education and Bilingualism, 16(3), 334-353. https://doi.org/10.1080/13670050.2013.777389

European Commission. (1995). White Paper on Education and Training. Teaching and Learning. Towards de Learning Society. Brussels: Archive of European Integration. Retrieved from http://europa.eu/docu ments/comm/white_papers/pdf/com95_590_en.pdf

Genesee, F., \& E. Hamayan (2016). CLIL in Context. Practical Guidance for Educators. Cambridge: Cambridge University Press.

Graham, K. M., Choi, Y., Davoodi, A., Razmeh, S., \& Dixon, L. Q. (2018). Language and Content Outcomes of CLIL and EMI: A systematic review. LACLIL, 11(1), 19-37. https://doi.org/10.5294/laclil.2018.11.1.2

Griva, E., Chostelidou, D., \& Panteli, P. (2014). Insider views of CLIL in Primary Education: Challenges and Experiences of EFL teachers. International Journal for Innovation Education and Research, 2(8), 31-53.

Hansen-Pauly, M. A., Bentner, G., Jovanovic, V., Zerbato, D., Llinares, A., Dafouz, E., Erades, C., García M., Carreras, A., Favili, F., Dale, L. Robinson, P. Hoffmanova, M., \& Novotna, J. (2009). Teacher education for CLIL across contexts: From scaffolding framework to teacher portfolio for Content and Language integrated learning. Retrieved from http://clil.uni.lu/CLIL/Project_files/CLIL_Project_Final_Report.pdf

Haukås, A. (2018). Teachers' Beliefs about Language Instruction. In H. Bøhn, M. Dypedahl, \& G. Myklevold (Eds.) Teaching and Learning English (pp. 343-357). Oslo, Cappelen Damm Akademisk.

Hunt, M. (2011).UK teachers' and learners' experiences of CLIL resulting from the EU-funded project ECLILT. 
Latin American Journal of Content and Language Integrated Learning, 4(1), 27-39. https://doi.org/10. 5294/laclil.2011.4.1.3

Hüttner, J., Dalton-Puffer, C., \& Smit, U. (2013). The power of beliefs: lay theories and their influence on the implementation of CLIL programmes. International Journal of Bilingual Education and Bilingualism, 16(3), 267-284. https://doi.org/10.1080/13670050.2013.777385

Infante, D., Benvenuto, G., \& Lastrucci, E. (2009). The effects of CLIL from the perspective of experienced teachers. In D. Marsh, P. Mehisto, D. Wolff, R. Aliaga, T. Asikainen, M. J. Frigols-Martín, S. Hughes, \& G. Langé (Eds.), CLIL Practice: Perspectives from the Field (pp. 156-163). Jyväskylä: University of Jyväskylä.

Johnson, K. E. (1994). The emerging beliefs and instructional practices of preservice English as second language teachers. Teaching and Teacher Education, 10(4), 439-452. https://doi.org/10.1016/0742-051X(94)90024-8

Joram, E., \& Gabriele, A. J. (1998). Preservice Teachers' Prior Beliefs: Transforming Obstacles into Opportunities. Teaching and Teacher Education, 14(2), 175-191. https://doi.org/10.1016/S0742-051X(97)00035-8

Juan-Garau, M., \& Salazar-Noguera, J. (2015). Introduction: The Relevance of CLIL Education in Achieving Multilingualism on the Global Stage. In M. Juan-Garau, \& J. Salazar-Noguera (Eds.), Content-based Language Learning in Multilingual Educational Environments (pp. 1-10). Cham: Springer. https://doi.org/10.1007/978-3-319-11496-5_1

Kagan, D. (1992). Professional Growth among Preservice and Beginning Teachers. Review of Educational Research, 62(2), 129-169. https://doi.org/10.3102/00346543062002129

Kelly, M., Grenfell, R., Allan, C., Kriza, C., \& McEvoy, W. (2004). European Profile for Language Teacher Education: A Frame of Reference. Brussels: European Commission.

Lancaster, N. (2016). Stakeholder perspectives on CLIL in a monolingual context. English Language Teaching, 9(2), 148-177. https://doi.org/10.5539/elt.v9n2p148

Lasagabaster, D. (2015). Different Educational Approaches to Bi- or Multilingualism and Their Effect on Language Attitudes. In M. Juan-Garau, \& J. Salazar-Noguera (Eds.), Content-based Language Learning in Multilingual Educational Environments (pp. 13-30). Cham: Springer. DOI 10.1007/978-3-319-11496-5_2

Lasagabaster, D., \& Ruiz de Zarobe, Y. (2010). CLIL in Spain: Implementation, Results and Teacher Training. Newcastle upon Tyne, UK: Cambridge Scholars Publishing.

Lasagabaster, D., \& Sierra, J. M. (2010). Immersion and CLIL in English: More differences than similarities. ELT Journal, 64(4), 376-395. https://doi.org/10.1093/elt/ccp082

Llurda, E. (2009). The decline and fall of the native speaker. In L. Wei, \& V. Cook (Eds.), Contemporary applied linguistics: Language teaching and learning (Vol. 1, pp. 37-53). Oxford: Continuum.

Llurda, E. (2016). 'Native speakers', English and ELT. Changing perspectives. In G. Hall (Ed.), The Routledge handbook of ELT (pp. 51-63). London: Routledge.

Lin, A. M. Y. (2015). Conceptualising the potential role of L1 in CLIL, Language, Culture and Curriculum, 28(1), 74-89. https://doi.org/10.1080/07908318.2014.1000926

Lin, A. M. Y. \& He, P. (2017). Translanguaging as Dynamic Activity Flows in CLIL Classrooms. Journal of Language, Identity \& Education, 16(4), 228-244. https://doi.org/10.1080/15348458.2017.1328283

Lo, Y. Y. (2015). How much L1 is too much? Teachers' language use in responde to students' abilities and classroom interaction in Content and Language Integrated Learning. International Journal of Bilingual Education and Bilingualism, 18(3), 270-288. https://doi.org/10.1080/13670050.2014.988112

Lorenzo F., Trujillo, F., \& Vez, J. M. (2011). Educación bilingüe: Integración de contenidos y segundas lenguas. Madrid, ES: Síntesis.

Lova Mellado, M., Bolarín Martínez, M. J., \& Porto Currás, M. (2013). Programas bilingües en Educación Primaria: Valoraciones de docentes. Porta Linguarum, 20, 253-268.

Maljers, A., Marsh, D., \& Wolff, D. (2007). Windows on CLIL. Content and Language Integrated Learning in the European Spotlight. Alkmaar: European Platform for Dutch Education.

Marsh, D. (2002). CLIL/EMILE - the European Dimension: Actions, Trends and Foresight Potential. Jyväskyla: University of Jyväskylä. 
Marsh, D., Mehisto, P., Wolff, D., \& Frigols Martín, M. J. (2010). The European Framework for CLIL Teacher Education. Graz, AT: European Center for Modern Languages.

Massler, U. (2012). Primary CLIL and its Stakeholders: What Children, Parents and Teachers Think of the Potential Merits and Pitfalls of CLIL Modules in Primary Teaching. International CLIL Research Journal, $1(4), 36-46$.

Mayring, P. (2014). Qualitative content analysis: theoretical foundation, basic procedures and software solution. Klagenfurt: GESIS -Leibniz Institute for the Social Sciences. Retrieved from https://www.psychopen.eu /fileadmin/user_upload/books/mayring/ssoar-2014-mayring-Qualitative_content_analysis_theoretical_foun dation.pdf

Méndez García, M. C. (2012). The potential of CLIL for intercultural development: A case study of Andalusian bilingual schools. Language and Intercultural Communication, 12(3), 196-213. https://doi.org/10.1080/14 708477.2012.667417

Méndez García, M. C., \& Pavón Vázquez, V. (2012). Investigating the coexistence of the mother tongue and the foreign language through teacher collaboration in CLIL contexts: Perceptions and practice of the teachers involved in the plurilingual programme in Andalusia. International Journal of Bilingual Education and Bilingualism, 15(5), 573-592. https://doi.org/10.1080/13670050.2012.670195

Mehisto, P., \& Asser H. (2007). Stakeholder Perspectives: CLIL Programme Management in Estonia. International Journal of Bilingual Education and Bilingualism, 10(5), 683-701. https://doi.org/10.216 7/beb466.0

Merino, J. A., \& Lasagabaster, D. (2015). CLIL as a way to multilingualism. International Journal of Bilingual Education and Bilingualism, 21(1), 79-92. https://doi.org/10.1080/13670050.2015.1128386

Milla Lara, M. D., \& Casas Pedrosa, A. (2018). Teacher Perspectives on CLIL Implementation: A Within-Group Comparison of Key Variables. Porta Linguarum, 29, 159-180.

Moate, J. (2011). The impact of foreign language mediated teaching on teachers' sense of professional integrity in the CLIL classroom. European Journal of Teacher Education, 34(3), 333-346. https://doi.org/10.10 $80 / 02619768.2011 .585023$

Moliner, M. (2013). The effects of CLIL from the perspective of in-service teachers in Salamanca (Castilla y León, Spain). Educaçao y Formaçao, 8, 200-217. Retrieved from http://www.exedrajournal.com/wp -content/uploads/2014/09/14.pdf

Morton, T. (2010). Using a Genre-Based Approach to Integrating Content and Language in CLIL: The Example of Secondary History. In C. Dalton-Puffer, T. Nikula, \& U. Smit (Eds.), Language Use and Language Learning in CLIL Classrooms (pp. 81-104). Amsterdam: John Benjamins. https://doi.org/10.1075/aals.7.05 mor

Muñoz, C. (2007). CLIL: Some Thoughts on Its Psycholinguistic Principles. Revista Española de Lingüistica Aplicada, 1, 17-26.

Ó Ceallaigh, T. J., Ní Mhurchú, S., \& Ní Chróinín, D. (2017) Balancing content and language in CLIL. The experiences of teachers and learners. Journal of Immersion and Content-Based Language Education, 5(1), 58-86. https://doi.org/10.1075/jicb.5.1.03oce

Pajares, M. (1992). Teachers' beliefs and educational research: Cleaning up a messy construct. Review of Educational Research, 62(3), 307-332. https://doi.org/10.3102/00346543062003307

Paran, A. (2013). Content and language integrated learning: Panacea or policy borrowing myth? Applied Linguistics Review, 4(2), 317-342. https://doi.org/10.1515/applirev-2013-0014

Pavón Vázquez, V., \& Rubio Alcalá, F. (2010). Teachers' Concerns and Uncertainties about the Introduction of CLIL Programmes. Porta Linguarum, 14, 45-58.

Pavón Vázquez, V., \& Ellison, M. (2013). Examining teacher roles and competences in Content and Language Integrated Learning (CLIL). Linguarum Arena, 4, 65-78.

Pavón Vázquez, V., \& Méndez García, M. C. (2017). Analysing teachers' roles regarding cross-curricular coordination in Content and Language Integrated Learning (CLIL). Journal of English Studies, 15, 235-260. https://doi.org/10.18172/jes.3227

Pavón Vázquez, V., \& Ramos Ordoñez, C. (2018). Describing the use of the L1 in CLIL: an analysis of L1 
communication strategies in classroom interaction. International Journal of Bilingual Education and Bilingualism. https://doi.org/10.1080/13670050.2018.1511681

Pena Díaz, C., \& M. Porto Requejo (2008). Teacher beliefs in a CLIL education project. Porta Linguarum, 10, 151-161.

Pérez Cañado, M. L. (2016a). From the CLIL craze to the CLIL conundrum: Addressing the current CLIL controversy. Bellaterra Journal of Teaching \& Learning Language \& Literature, 9(1), 9-31. https://doi.or $\mathrm{g} / 10.5565 / \mathrm{rev} / \mathrm{jt} 13.667$

Pérez Cañado, M. L. (2016b). Teacher training needs for bilingual education: in-service teacher perceptions. International Journal of Bilingual Education and Bilingualism, 19(3), 266-295. https://doi.org/10.1080/136 70050.2014.980778

Pérez Cañado, M. L. (2017). CLIL Teacher Education: Where do we Stand and Where do we Need to Go? In M. E. Gómez Parra, \& R. Johnstone (Eds.), Bilingual Education: Educational Trends and Key Concepts (pp. 129-144). Madrid, ES: Ministerio de Educación.

Pérez Cañado, M. L. (2018). Innovations and Challenges in CLIL Teacher Training. Theory Into Practice, 57(3), 1-10. https://doi.org/10.1080/00405841.2018.1492238

Pérez-Vidal, C. (2015). Languages for All in Education: CLIL and ICLHE at the Crossroads of Multilingualism, Mobility and Internationalisation. In M. Juan-Garau, \& J. Salazar-Noguera (Eds.), Content-based Language Learning in Multilingual Educational Environments (pp. 13-30). Cham: Springer. https://doi.org/10.10 07/978-3-319-11496-5_3

Portolés, L. \& Martí O. (2018). Teachers' beliefs about multiligual pedagogies and the role of initial training. International Journal of Multilingualism. https://doi.org/10.1080/14790718.2018.1515206

Querol-Julián, M., Ruiz-Madrid, N., \& Ruiz Garrido, M. F. (2015). Reflexiones del profesorado universitario sobre la introducción del inglés como lengua de instrucción. E-Aesla, 1.

Richards, J. C. (1998). Beyond training. Cambridge, U.K.: Cambridge University Press.

Richardson, V. (1996). The role of attitudes and beliefs in learning to teach. In J. Sikula (Ed.), Handbook of Research on Teacher Education (2nd ed., pp. 102-119). New York: Macmillan.

Ruiz de Zarobe, Y. (2008). CLIL and foreign language learning: A longitudinal study in the Basque Country. International Journal of CLIL Research, 1(1), 60-73.

Ruiz de Zarobe, Y. (2013). CLIL implementation from policy-makers to individual initiatives. International Journal of Bilingual Education and Bilingualism, 16(3), 231-243. https://doi.org/10.1080/13670050.2013. 777383

Ruiz de Zarobe, Y. (2015). The Effects of Implementing CLIL in Education. In M. Juan-Garau, \& J. Salazar-Noguera (Eds.), Content-based Language Learning in Multilingual Educational Environments (pp. 51-68). Cham: Springer. https://doi.org/10.1007/978-3-319-11496-5_4

Ruiz de Zarobe, Y., \& Cenoz, J. (2015). Way forward in the twenty-first century in content-based instruction: moving towards integration. Language, Culture and Curriculum, 28(1), 90-96. https://doi.org/10.1080/079 08318.2014.1000927

San Isidro, X. (2018). Innovations and Challenges in CLIL Implementation in Europe. Theory Into Practice, 57(3), 185-195. https://doi.org/10.1080/00405841.2018.1484038

Schreier, M. (2012). Qualitative Content Analysis in Practice. Los Angeles London New Delhi Singapore Washington DC: SAGE.

Serra, C. (2007). Assessing CLIL at Primary School: A Longitudinal Study. International Journal of Bilingual Education and Bilingualism, 10(5), 582-602. https://doi.org/10.2167/beb461.0

Shulman, L. (1987). Knowledge and teaching: Foundations of the new reform. Harvard Educational Review, 57(1), 1-22. https://doi.org/10.17763/haer.57.1.j463w79r56455411

Skinnari, K., \& Bovellan, E. (2016). CLIL teachers' beliefs about integration and about their professional roles: Perspectives from a European context. In T. Nikula, E. Dafouz, P. Moore, \& U. Smit (Eds.), Conceptualising integration in CLIL and multilingual education (pp. 145-167). Bristol: Multilingual Matters. https://doi.org/10.21832/9781783096145-010

Ting, Y. L. T. (2010). CLIL appeals to how the brain likes its information; Examples from CLIL-(Neuro) Science, 
International CLIL Research Journal, 1(3), 1-18. https://doi.org/10.1243/14680874JER511

Travé González, G. (2013). Un estudio sobre las representaciones del profesorado de Educación Primaria acerca de la enseñanza bilingüe. Revista de Educación, 361.

Travé González, G. (2016). La enseñanza bilingüe en Andalucía. Un estudio a partir de las voces de los docentes. Revista Electrónica de Investigación y Docencia (REID), 16, 51-74.

Travé González, G., \& Soto Rosales, A. (2014). La enseñanza bilingüe según el profesorado de primaria: características, facilitadores y dificultades. Investigación en la Escuela, 84, 73-86. Retrieved from https://idus.us.es/xmlui/bitstream/handle/11441/59765/R84-6.pdf? sequence=1\&isAllowed=y

van Kampen, E., Meirink, J., Admiraal, W., \& Beery, A. (2018). Do we all share the same goals for content and language integrated learning (CLIL)? Specialist and practitioner perceptions of 'ideal' CLIL pedagogies in the Netherlands. International Journal of Bilingual Education and Bilingualism, 21(2), 222-236. https://doi.org/10.1080/13670050.2017.1411332

Viebrock, B. (2012). The situation in the CLIL classroom is quite different -or is it? Teachers' mindsets, methodological competences and teaching habits. In D. Marsh, \& O. Meyer (Eds.), Quality interfaces: examining evidence and exploring solutions in CLIL (pp. 78-90). Eichstaett: Eichstaett Academic Press.

Wegner, A. (2012). Seeing the bigger picture: what students and teachers think about CLIL. International CLIL Research Journal, 1(4), 29-35.

Wolff, D. (2012). The European Framework for CLIL Teacher Education. Sinergies Italie, 8, 105-116. Retrieved from https://www.unifg.it/sites/default/files/allegatiparagrafo/06-07-2017/wolff_european_framework_ for_clil_teacher_education.pdf

Woods, D. (1996). Teacher Cognition in Language Teaching: Beliefs, decision-making and classroom practice. Cambridge: Cambridge University Press.

\section{Appendix}

The tables below provide an overview of the reasons given to justify the "pros" and "cons" of implementing this teaching approach in Primary Education. Both the category and subcategory names as well as the description attached result from having translated into English most of the essays that, as detailed in section 3.2, were originally written in either Spanish or Catalan.

Table 1. Learning gains/losses of CLIL prior to instruction

\begin{tabular}{|c|c|c|c|c|}
\hline Categories & Sub-categories & Description & $\begin{array}{l}\mathrm{N} \\
\text { of } \mathrm{P}\end{array}$ & $\begin{array}{l}\text { \% of } \\
\mathrm{P}\end{array}$ \\
\hline \multirow[t]{10}{*}{$>$ COMMUNICATION } & $>$ INPUT & $\begin{array}{l}\text { >quantity of INPUT: more contact hours with } \\
\text { the TL thanks to teacher talk }\end{array}$ & 27 & $25 \%$ \\
\hline & & $\begin{array}{l}\text { > quality of INPUT favours unconscious learning } \\
\text { of grammar and vocabulary }\end{array}$ & 8 & $7 \%$ \\
\hline & >OUTPUT & $\begin{array}{l}>\text { meaningful oriented output closer to real-life: } \\
\text { "to use language is to learn language" }\end{array}$ & 33 & $30 \%$ \\
\hline & & $>$ focus on interaction & 13 & $12 \%$ \\
\hline & & >fluency & 4 & $4 \%$ \\
\hline & & $\begin{array}{l}\text { > vocabulary and expressions for everyday life } \\
\text { communication }\end{array}$ & 18 & $16 \%$ \\
\hline & CLIL \& EFL & $>$ skill-focused & 23 & $21 \%$ \\
\hline & & $\begin{array}{l}>\text { content-specific vocabulary absent from the } \\
\text { EFL class }\end{array}$ & 29 & $26 \%$ \\
\hline & & $\begin{array}{l}\text { innovative language teaching alternative to FI in } \\
\text { EFL regular classes }\end{array}$ & 29 & $26 \%$ \\
\hline & & complementary to EFL & 4 & $4 \%$ \\
\hline
\end{tabular}




\begin{tabular}{|c|c|c|c|c|}
\hline & the M-factor & bilingualism & 1 & $1 \%$ \\
\hline & & plurilingualism & 0 & $0 \%$ \\
\hline$<$ COMMUNICATION & $\mathrm{L} 1(\mathrm{~s})$ & $\begin{array}{l}\text { detrimental for L1 (s): languages should be } \\
\text { learnt one at a time }\end{array}$ & 6 & $5 \%$ \\
\hline \multirow[t]{2}{*}{$>$ CONTENT } & >subject matter & $\begin{array}{l}\text { enhances in-depth knowledge due to the higher } \\
\text { attention and reflection involved }\end{array}$ & 25 & $23 \%$ \\
\hline & >interdisciplinary & $\begin{array}{l}\text { cross-curricular approach enriches subject } \\
\text { matter }\end{array}$ & 2 & $2 \%$ \\
\hline \multirow[t]{4}{*}{$<$ CONTENT } & $\begin{array}{l}<\text { academic } \\
\text { achievement }\end{array}$ & mastery of contents reduced & 65 & $59 \%$ \\
\hline & $<$ instruction & transmissive teaching model based on lecturing & 17 & $15 \%$ \\
\hline & $<$ comprehension & $\begin{array}{l}\text { limits students' understanding of contents due to } \\
\text { the English only rule }\end{array}$ & 36 & $33 \%$ \\
\hline & $<$ subject matter & $\begin{array}{l}\text { lessons slow down due to longer explanations } \\
\text { needed to avoid translating to the L1 (s) }\end{array}$ & 22 & $20 \%$ \\
\hline \multirow[t]{3}{*}{$>$ COGNITION } & $\begin{array}{l}>\text { cognitive } \\
\text { development }\end{array}$ & $>$ sustained attention and thinking skills needed & 5 & $5 \%$ \\
\hline & $>$ critical thinking & $>$ reasoning based on logical evidence & 0 & $0 \%$ \\
\hline & $>$ creative thinking & develops students' imagination & 0 & $0 \%$ \\
\hline$>$ CULTURE & ICC & >awareness of self and "otherness" & 0 & $0 \%$ \\
\hline
\end{tabular}

Table 2. Learning gains/losses of CLIL after instruction

\begin{tabular}{|c|c|c|c|c|c|c|}
\hline \multirow[b]{2}{*}{ Categories } & \multirow[b]{2}{*}{ Sub-categories } & \multirow[b]{2}{*}{ Description } & \multicolumn{2}{|c|}{ PRETEST } & \multicolumn{2}{|c|}{ POSTTEST } \\
\hline & & & $\begin{array}{l}\mathrm{N} \text { of } \\
\mathrm{P}\end{array}$ & $\begin{array}{l}\% \\
\text { of P }\end{array}$ & $\begin{array}{l}\mathrm{N} \text { of } \\
\mathrm{P}\end{array}$ & $\begin{array}{l}\% \text { of } \\
\mathrm{P}\end{array}$ \\
\hline \multirow[t]{11}{*}{$>$ COMMUNICATION } & $>$ INPUT & $\begin{array}{l}\text { > quantity of INPUT: more contact } \\
\text { hours with the TL thanks to } \\
\text { teacher talk }\end{array}$ & 27 & $25 \%$ & 21 & $19 \%$ \\
\hline & & $\begin{array}{l}\text { >quality of INPUT favours } \\
\text { unconscious learning of grammar } \\
\text { and vocabulary }\end{array}$ & 8 & $7 \%$ & 24 & $22 \%$ \\
\hline & $>$ OUTPUT & $\begin{array}{l}>\text { meaningful oriented output closer } \\
\text { to real-life: "to use language is to } \\
\text { learn language" }\end{array}$ & 33 & $30 \%$ & 43 & $39 \%$ \\
\hline & & $>$ focus on interaction & 13 & $12 \%$ & 5 & $4 \%$ \\
\hline & & $>$ fluency & 4 & $4 \%$ & 2 & $2 \%$ \\
\hline & & $\begin{array}{l}\text { >vocabulary and expressions for } \\
\text { everyday life communication }\end{array}$ & 18 & $16 \%$ & 18 & $16 \%$ \\
\hline & CLIL \& EFL & $>$ skill-focused & 23 & $21 \%$ & 9 & $8 \%$ \\
\hline & & $\begin{array}{l}\text { >content-specific vocabulary } \\
\text { absent from the EFL class }\end{array}$ & 29 & $26 \%$ & 20 & $18 \%$ \\
\hline & & $\begin{array}{l}\text { innovative language teaching } \\
\text { alternative to FI in EFL regular } \\
\text { classes }\end{array}$ & 29 & $26 \%$ & 26 & $24 \%$ \\
\hline & & complementary to EFL & 4 & $4 \%$ & 4 & $4 \%$ \\
\hline & the M-factor & bilingualism & 1 & $1 \%$ & 4 & $4 \%$ \\
\hline
\end{tabular}




\begin{tabular}{|c|c|c|c|c|c|c|}
\hline & & plurilingualism & 0 & $0 \%$ & 8 & $7 \%$ \\
\hline$<$ COMMUNICATION & $\mathrm{L1}(\mathrm{s})$ & $\begin{array}{l}\text { detrimental for L1 (s): languages } \\
\text { should be learnt one at a time }\end{array}$ & 6 & $5 \%$ & 10 & $9 \%$ \\
\hline \multirow[t]{2}{*}{$>$ CONTENT } & >subject matter & $\begin{array}{l}\text { enhances in-depth knowledge of } \\
\text { contents due to the higher attention } \\
\text { and reflection involved }\end{array}$ & 25 & $23 \%$ & 23 & $21 \%$ \\
\hline & >interdisciplinary & $\begin{array}{l}\text { cross-curricular approach enriches } \\
\text { subject matter }\end{array}$ & 2 & $2 \%$ & 1 & $1 \%$ \\
\hline \multirow[t]{4}{*}{$<$ CONTENT } & $\begin{array}{l}<\text { academic } \\
\text { achievement }\end{array}$ & mastery of contents reduced & 65 & $59 \%$ & 49 & $44 \%$ \\
\hline & $<$ instruction & $\begin{array}{l}\text { transmissive teaching model based } \\
\text { on lecturing }\end{array}$ & 17 & $15 \%$ & 16 & $14 \%$ \\
\hline & $<$ comprehension & $\begin{array}{l}\text { limits students' understanding of } \\
\text { contents due to the English only } \\
\text { rule }\end{array}$ & 36 & $33 \%$ & 22 & $20 \%$ \\
\hline & $<$ subject matter & $\begin{array}{l}\text { lessons slow down due to longer } \\
\text { explanations needed to avoid } \\
\text { translating to the L1 (s) }\end{array}$ & 22 & $20 \%$ & 20 & $18 \%$ \\
\hline \multirow[t]{3}{*}{$>$ COGNITION } & $\begin{array}{l}>\text { cognitive } \\
\text { development }\end{array}$ & $\begin{array}{l}\text { >sustained attention and thinking } \\
\text { skills needed }\end{array}$ & 5 & $5 \%$ & 14 & $13 \%$ \\
\hline & $>$ critical thinking & $\begin{array}{l}\text { >reasoning based on logical } \\
\text { evidence }\end{array}$ & 0 & $0 \%$ & 1 & $1 \%$ \\
\hline & $>$ creative thinking & develops students' imagination & 0 & $0 \%$ & 1 & $1 \%$ \\
\hline$>$ CULTURE & $\mathrm{ICC}$ & $>$ awareness of self and "otherness" & 0 & $0 \%$ & 10 & $9 \%$ \\
\hline
\end{tabular}

\section{Copyrights}

Copyright for this article is retained by the author(s), with first publication rights granted to the journal.

This is an open-access article distributed under the terms and conditions of the Creative Commons Attribution license (http://creativecommons.org/licenses/by/4.0/). 